\title{
Luminescence of Higher Mushrooms
}

\author{
Vladimir S. Bondar ${ }^{\mathrm{a}, \mathrm{b} *}$, \\ Osamu Shimomura ${ }^{\text {a,c }}$ and Josef I. Gitelson ${ }^{a, b}$ \\ ${ }^{a}$ Siberian Federal University, \\ 79 Svobodny, Krasnoyarsk, 660041 Russia \\ ${ }^{b}$ Institute of Biophysics SB RAS, \\ 50/50 Akademgorodok, Krasnoyarsk, 660036 Russia \\ ${ }^{c}$ Marine Biological Laboratory, Woods Hole, \\ Massachusetts, 02543 United States of America ${ }^{1}$
}

The review highlights the results of experimental studies on fungal luminescence carried out during last two centuries. Present concepts on the luminescent system and light emission mechanism in higher fungi are discussed.

Keywords: higher mushrooms, bioluminescence, chemiluminescence, luciferase, luciferin, emitter.

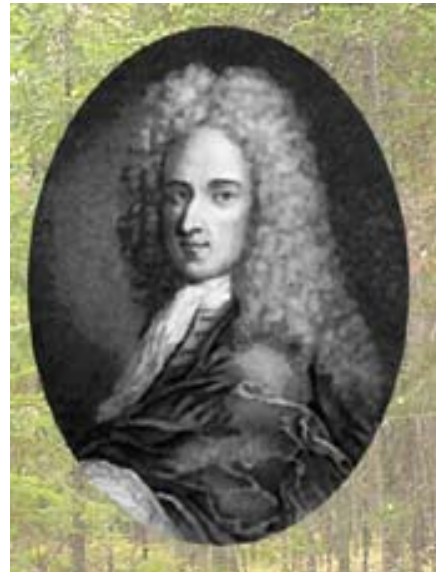

«Fungi-are the devil product that disturbs the general harmony of nature, to confuse the most talented researchers and get of young botanists in despair»

(Vaillant Sébastien, 1669-1722).
Unique position the kingdom of mushrooms holds in the living nature was sagaciously foretold by French botanist and mycologist Sebastien Vaillant whose words are given in the epigraph of this paper. Fabulous foresight at the turn of the XVII ${ }^{\text {th }}$ and XVIII ${ }^{\text {th }}$ centuries when nothing was known about biochemistry, not to mention genetics. Yet, further development of biology proves equidistance of the kingdom of mushrooms from both animals and plants. But traditions die hard and up to now mycology is studied in universities in the course of general botany.

The mechanism of bioluminescence in fungi, the knowledge of which is reviewed in this work, also proves their unique position. Fungi

* Corresponding author E-mail address: bondvs@mail.ru

(C) Siberian Federal University. All rights reserved 


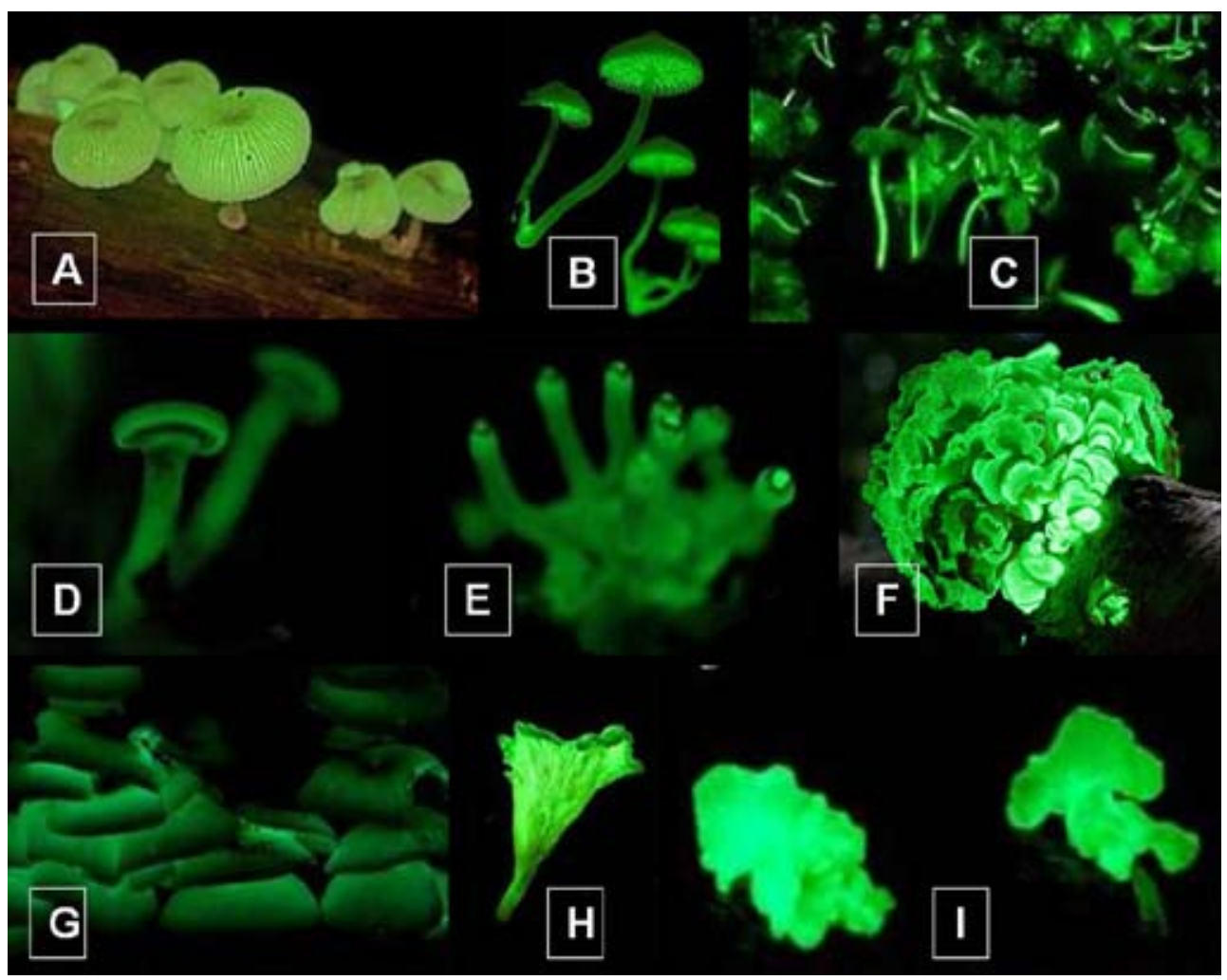

Fig. 1. Emission of visible light by mushrooms: A - Mycena lampadis; B - Filoboletus sp.; C - Mycena sp.; D, E, F - Panellus stipticus; G, H - Omphalotus sp.; I - Neonothopanus nambi. Photographs (A - H) - from official sites of National Geographic (http://news.nationalgeographic.com/news/) and Flikr ${ }^{\circledR}$ from Yahoo (http://www. flickr.com/); photo (I) was kindly provided by Vietnamese researcher Dao Thi Van (Bio-Lumi Co., Ltd., Ho Chi Minh City, Vietnam)

share bioluminescence capability with animals and bacteria, however, the deeper the insight into the mechanism of this amazing phenomenon the more obvious is its fundamental distinction in mushrooms from the luminescence mechanism of animals and plants.

Bioluminescence of fungi, emission of light visible with unaided eye (Fig. 1), has been known down the ages. Several authors (Johnson, Haneda 1966; Shimomura, 2006) note, that according to Harvey, this phenomenon was described as early as by Aristotle (fourth century BC) and Pliny the Elder (first century AC) in «Historia Naturalis» (Harvey, 1952, 1957). Describing luminescence of rotting tree Aristotle called this phenomenon «shining wood» and «fox fire», while Pliny the
Elder noted that luminescent white mushrooms with sweetish taste and exhibiting pharmacological effect can be found on rotting trees. G.E. Rumph wrote in «Herbarium Amboiense», that residents of Moluccas (Indonesia) illuminated their way in a dark forest by fruiting bodies of bioluminescent mushrooms (quote from Harvey, 1957). Harvey (1957) noted that on the one hand the aboriginals of Micronesia used luminescent mushrooms as decorations for ritual dances to paint their faces to intimidate enemies, on the other hand luminous mushrooms were frequently destroyed because to find them was considered an ill omen. Emotions of people who saw for the first time the mushrooms glow is anyone's guess. Surviving rave records of seafarers of Ancient times speak 
of the mind-bending effect of luminescence of marine organisms. The emotional impact of luminescence of mushrooms was probably not less (Fig. 1).

Aristotle's and Pliny the Elder's works and reports of botanists about wide occurrence of luminescent mushrooms notwithstanding, for a long time researchers focused their efforts on luminescence of rotting trees, but not the mushrooms, as they are. For instance, well known is the work by Robert Boyle (1668), who used an air pump to demonstrate necessity of air for wood to glow. Therefore, the most important discoveries pertaining directly to bioluminescence of mushrooms were made by researchers much later - the first half of the XIX ${ }^{\text {th }}$ century. Scientific works of this period give some insight into the way in which the views of researchers studying luminescence of wood and trying to understand the cause of this phenomenon transformed. J.F. Heller, Professor of the University of Vienna, was among the first who associated luminescence of rotting wood with presence of mushrooms; thorough examinations by von Derschau et al. made possible to conclude that luminescence of wood is associated with presence of fungal mycelium (von Derschau's letter was published in 1823 by the German botanist T.F.L. Nees von Esenbeck); Conrade Gesner, Francis Bacon and Thomas Bartholin left their records about glowing soil (quote by Harvey, 1952, 1957). Luminescence of mushrooms was observed in 1815 by P. Heinrich; J.F. Heller noted in 1853 that luminescence is a biological process (quote by Yachevsky, 1933).

The pioneer works of the first half of the XIX $^{\text {th }}$ century mentioned above opened the way and largely facilitated further studies of fungal luminescence. In 1855 J.H. Fabre experimentally established basic parameters of mushroom bioluminescence and formulated two important conclusions: $1-$ luminescence is not attended by heat - light goes down in vacuum, in hydrogen and in carbon dioxide; 2 - luminescence does not depend on humidity, temperature, or external light, and does not become brighter in pure oxygen (quote from Harvey, 1957). J. Schmitz made a detailed description of rhizomorphs; F. Ludwig presented his dissertation on the luminescence of mushrooms and wood; $\mathrm{H}$. Molisch published in 1904 a monograph on luminous plants (quote by Yachevsky, 1933).

It should be mentioned that in the two recent centuries a considerable number of the species of luminous mushroom were found; most of them belong to basidiomycetes class (Shimomura, 2006). By now luminous mushrooms have been found in North and South America, Europe, Asia, Australia, and Africa. The list keeps steadily growing because more and more new species are found, specifically in the subtropical and tropical zones of the globe where natural conditions are most favorable for their habitation. While in the first half of the $\mathrm{XX}^{\text {th }}$ century A.A. Yachevsky (1933) reported only 28 species of luminous mushrooms, by the end of the century their number had grown to 40 species (Wassink, 1978; Herring, 1994). Modern methods of identifying biological objects allowed Desjardin et al. (2008) to attribute about 70 species of basidiomycetes to luminous mushrooms. Further studies of fungal bioluminescence made possible to put in the list already 80 species of luminous mushrooms, not including synonyms (Vydryakova et al., 2009). Recently seven more new species of luminous mushrooms were found; the authors attributed them to Mycena family (Desjardin et al., 2010).

Even though mushroom bioluminescence has been studied out for many years, research is focused on three main directions. They are: to develop methods of cultivating luminous mushrooms under laboratory conditions (Endo et al., 1970; Bermudes et al., 1990; Weitz et al., 2001; Mendes et al., 2008; Dao, 2009), to study 


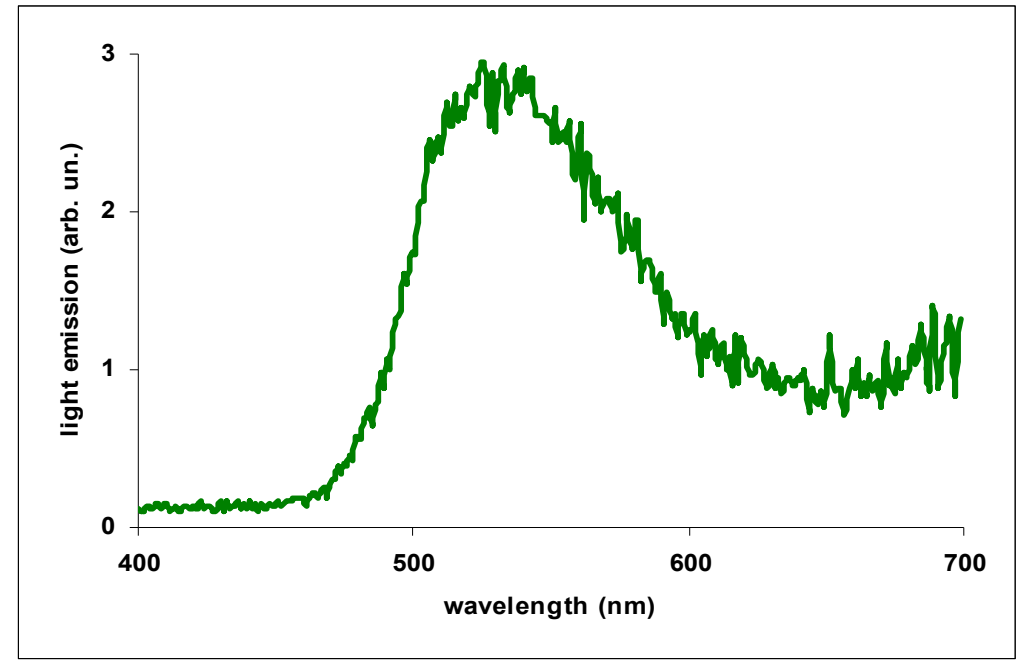

Fig. 2. Bioluminescence spectrum of N. nambi mycelium in vivo (Bondar et al., 2011)

molecular organization of the luminescent system and the mechanisms of mushroom luminescence (Kawamura, 1915; Airth, McElroy, 1959; Airth, Foerster, 1962; Kuwabara, Wassink, 1966; Kamzolkina et al., 1983; Shimomura, 1992; Shimomura et al., 1993; Shimomura, 2006; Oliveira, Stevani, 2009; Bondar et al., 2011; Oliveira et al., 2012a), and to study feasibility of applying fungal luminescence for analysis (Weitz et al., 2002; Horswell et al., 2005; Brock et al., 2008; Vydryakova et al., 2009; Mendes, Stevani, 2010).

It is common knowledge that bioluminescent mushrooms are generally saprophytes (less frequently - pathogenes) of plants. At different stages of their life cycle they emit greenish light (Fig. 1) with maximum in range 520-530 nm (Van den Burg, 1943; Endo et al., 1970; Lavelle et al., 1972; O'Kane et al., 1990; Shimomura, 2006; Desjardin et al., 2008; Bondar et al., 2011). For instance, in representatives of Mycena and Omphalotus genera both mycelium and fruiting body can glow, while in the species of Armillarea genus - only mycelium and rhizomorphs. A luminous mushroom emits light only for a certain period (periods) of its life cycle; after and before that period, it practically does not glow (Shimomura, 2006). On the whole the luminescence of younger fruiting bodies and young actively growing mycelium is brighter than mature fruiting bodies and old mycelium, even though the intensity of their luminescence varies widely with species and environment.

On the one hand, the identical maximum of light emission of luminous mushrooms (Fig. 2) suggests the similarity, if not identity of their molecular basis. This suggestion can be made at least for the mushrooms whose emission spectra have been studied (see above). However, the similarity might be only with the terminal emitters of luminescence in different mushroom species, like identical terminal emitter - green fluorescent protein (GFP) common for animals with different bioluminescent systems (Shimomura et al., 1962).

Growth and bioluminescence conditions have been studied for a small number of luminous mushrooms only: Armillaria mellea (Vahl.: Fr.) P. Kumm., Panellus stipticus (Bull.: Fr.) P. Karst., Mycena citricolor (Berk. \& M.A. Curtis) Sacc., Omphalotus olearius (DC. Fr.) Sing., Gerronema viridilucens Desjardin, Capelari \& Stevani, 


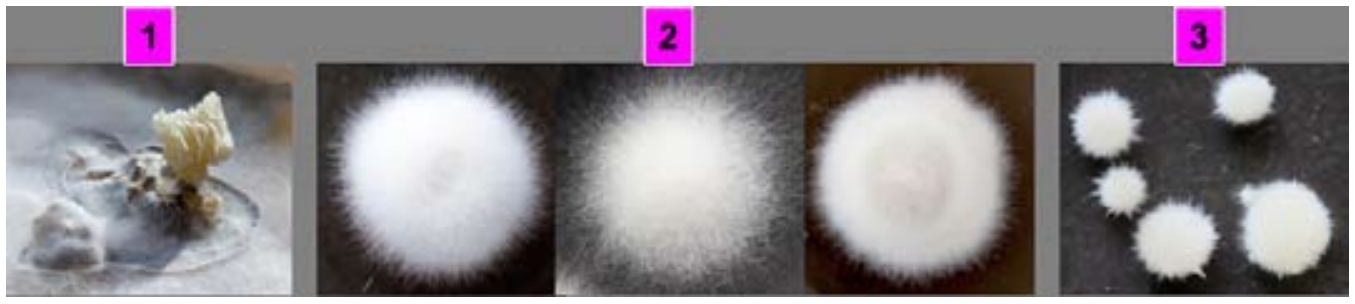

Fig. 3. Different methods of cultivating luminous mushrooms under laboratory conditions. The photographs show the appearance of: 1 - fruiting body of $N$. nambi, 2 - mycelium of $A$. borealis cultivated in Petri dishes on liquid nutrient media of different composition, 3 - globules of $N$. nambi mycelium grown deep in vials in liquid nutrient medium. The samples were produced by S.E. Medvedeva, E.K. Rodicheva and N.S. Manukovsky, researchers of the Institute of Biophysics of SB RAS (photo by E.S. Medvedeva)
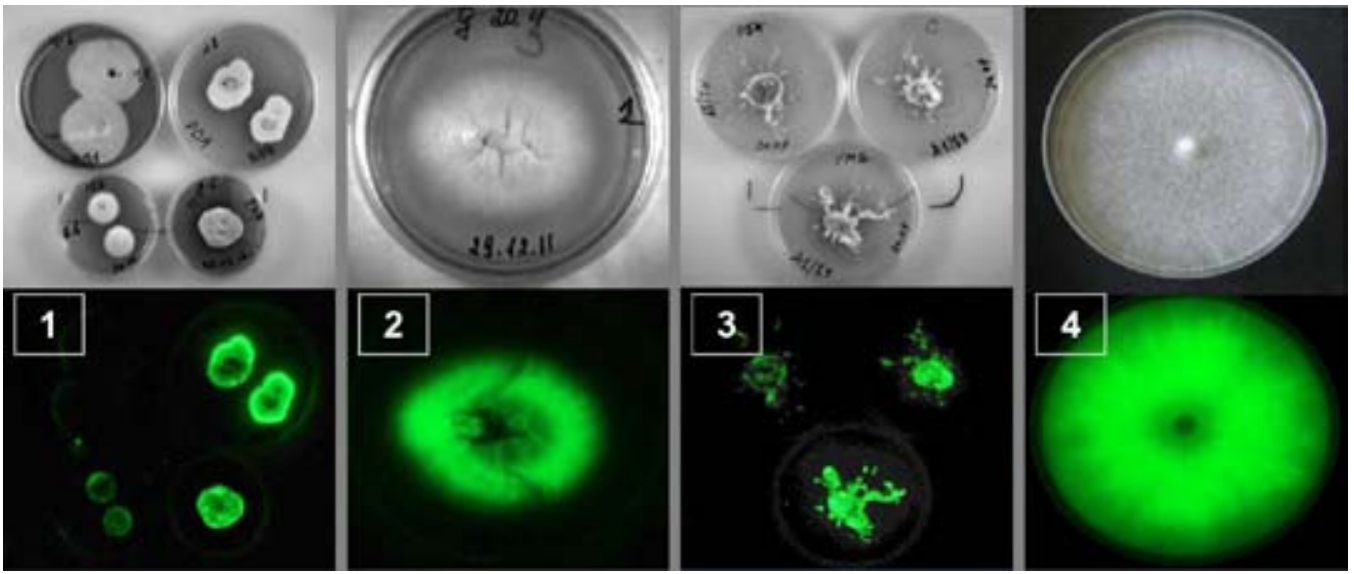

Fig. 4. Appearance (top) and luminescence (bottom) of the mycelium of different mushroom species grown in Petri dishes on liquid and solid nutrient media. $1-$ A. borealis, $2-$ P. stipticus, $3-A$. mellea, $4-N$. nambi. Bioluminescence intensity of mycelium samples was recorded with Universal Hood II (USA) system. The samples were produced by S.E. Medvedeva, K.V. Purtov and O.A. Mogilnaya, researchers of the Institute of Biophysics of SB RAS (photo by S.E. Medvedeva and K.V. Purtov)

Neonothopanus nambi (Speg.) R.H. Petersen \& Krisai (Bermudes et al., 1990; Weitz et al., 2001; Mendes et al., 2008; Dao, 2009; Vydryakova et al., 2009; Bondar et al., 2011). Mihail and Bruhn (2007) recorded the weak luminescence of pieces of mushroom fruiting bodies in many species of basidiomycetes. Wood-destroying fungi are, however, specified by substantially higher luminescence (visible bioluminescence). Intensity of luminescence of these species correlates with the activity of enzymes of the secondary metabolism participating in lignin destruction (Lingle, 1989, 1993; Bermudes et al., 1992).
Evidently, the microbiological works aimed to develop methods and to optimize cultivation conditions for luminous mushrooms (Fig. 3) are of primary significance in investigating fungal bioluminescence. Production under laboratory conditions of mushroom biomass (mycelium, fruiting bodies) with steady glow (Fig. 4) opens new opportunities for a broad range of studies: morphological strains of luminous mushrooms; structural-functional organization of mushroom luminescence systems; feasibility of the practical application of fungal luminescence for analysis. 
Along with other light emitting organisms and their bioluminescence systems (e.g. bacteria, coelenterate and fireflies) that are widely used in diverse analytical applications (Morin, 1974; Blinks et al., 1976; Ugarova, Brovko, 1981; Blinks et al., 1982; Gitelson et al., 1984; Kratasyuk, Gitelson, 1987; Ugarova et al., 1987; Ugarova et al., 1993; Illarionov et al., 2000; Shimomura, 2006), the luminous mushrooms are of real interest as luminescent markers in developing new luminescent microanalysis methods for biology, biotechnology and medicine. Long continued (from several days to several weeks) luminescence of mushrooms in a wide $\left(4^{\circ} \mathrm{C}-\right.$ $50^{\circ} \mathrm{C}$ ) temperature range (Yachevsky, 1933), the feasibility of cultivating under artificial conditions, and the production of biomass of aerial and in-depth mycelium (see above) make possible to predict their use to develop new bioluminescent assays. However, the structuralfunctional organization and the mechanisms of light emission of the luminescence system of mushrooms are currently not quite clear, and it is difficult to correctly assess the potential and prospects of employing fungal bioluminescence for practical purposes (e.g. for analytics).

However, even now several research groups (in Germany, England and Brazil) verify the feasibility of employing bioluminescent mushrooms as an indicator test object for bioassays. Luminous mushrooms A. mellea, $M$. citricolor and $G$. viridilucens were used to develop toxicity tests (Weitz et al., 2002; Horswell et al., 2005; Mendes, Stevani, 2010). Specifically, luminous mushrooms were used to detect toxicity of 3,5-dichlorophenol, pentachlorophenol and salts of heavy metals (Weitz et al., 2002). These compounds have been shown to inhibit luminescence of mycelium of $A$. mellea and $M$. citricolor; mycelium of $A$. mellea was found to be more resistant to the effect of 3,5-dichlorophenol than mycelium of $M$. citricolor. Mendes and
Stevani (2010) showed feasibility of employing luminous mushroom $G$. viridilucens as a biomarker to detect ions of heavy metals $(\mathrm{Pb}, \mathrm{Cd}$, Al). Luminous globular mycelium of $A$. mellea and $M$. citricolor as test objects were used by researchers in Great Britain and New Zealand (Hollis, 1999; Horswell et al., 2005). Using luminous mushroom-based bioassays to detect various toxic agents the authors of the above works noted that on the whole $\mathrm{EC}_{50}$ value for fungal luminescence under the effect of toxic agents was of the same order as the bacterial bioassays (Hollis, 1999, 2000; Horswell et al., 2005; Mendes, Stevani, 2010).

The luminescence of mushrooms has been studied for more than a hundred years. However, it should be noted, that the structure of luminescence system of luminous mushrooms and mechanism of light emission so far remain an enigma, distinctly differing from the bioluminescence systems of bacteria and many animal species (flagellate, coelenterate, worms, insects, crustaceans, mollusks, fish) decoded in recent decades (Shimomura, 2006). There is no consensus of opinion among the specialists of fungal bioluminescence about the molecular-cellular organization and light emission mechanism of the luminescence system of higher mushrooms. Currently conventional can be assumed two alternative concepts. According to the first, mushroom luminescence is determined by functioning of the luciferaseluciferin system (Airth, McElroy, 1959; Airth, Foerster, 1962; Kamzolkina et al., 1983; Kamzolkina et al., 1984; Oliveira, Stevani, 2009; Oliveira et al., 2012a). According to the second, mushroom luminescence is associated with oxidation of organic substrates and takes place without participation of a specialized enzyme (Shimomura, 1989; Shimomura, 2006; Bondar et al., 2011; Gitelson et al., 2012a; Bondar et al., 2012a; Gitelson et al., 2012b; Bondar et al., 2012b; 


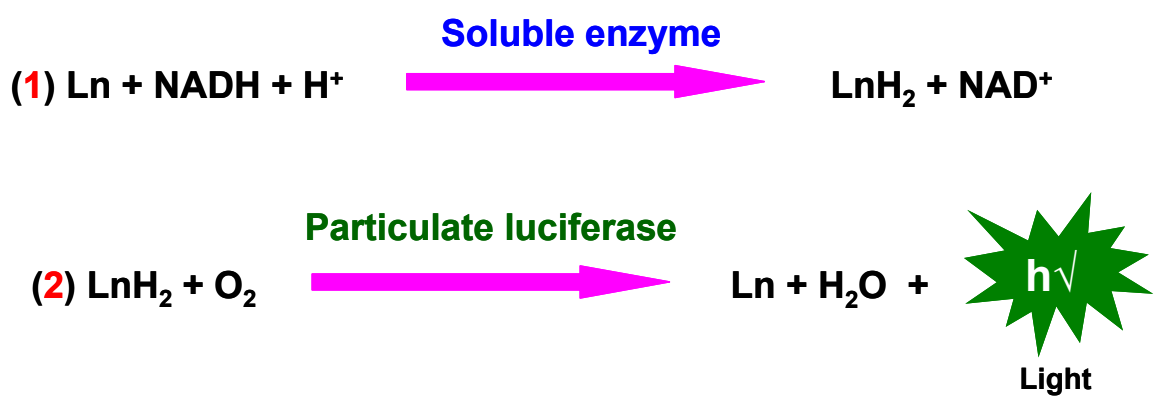

Fig. 5. The two-stage luciferin-luciferase reaction in light-emitting mushrooms proposed by Airth and Foerster (Shimomura, 2006)

Dao et al., 2012). Researchers adhering to the second concept express doubts about the presence of a specialized enzyme (luciferase) in fungi.

Efforts of many researchers to demonstrate luciferin-luciferase reaction in luminous mushrooms have been failing for a long time (Harvey, 1952; Shimomura, 2006). As early as at the beginning of the previous century Ewart (1906) and Kawamura (1915) experimented with cold and hot extracts from Pleurotus candescens and P. japonicus mushrooms to demonstrate the luciferin-luciferase reaction by Dubois pattern (Dubois, 1887), which he used to study luminescent systems of bivalve mollusk Pholas dactylus and Indian click-beetle Pyrophorus sp. Attempts of both researchers failed. Somewhat later Harvey (1922) used the Dubois procedure to study bioluminescence of $A$. mellea, $O$. olearius and $P$. stipticus mushrooms; he did not observe luminescence either. The author suggested that the result was negative due to low concentration and instability of luciferin or luciferase in the extracts. Buller (1924) tried to extract luciferin-luciferase system from $P$. stipticus mushroom, crushing the mushroom between two slides. In gradual destruction by crushing the biomass decreased luminescence until complete elimination. The author noted that mushroom (fresh or dried) wetted with water can exhibit luminescence, however, this effect was not observed after the dried mushroom was ground into powder. He suggested that mushroom destruction chemically inactivates components involved in bioluminescent reaction, e.g. oxidation of luciferin and (or) luciferase by substances, which prior to that were in individual cellular compartments.

It was only in the beginning of the second half of the previous century that studies of Airth and McElroy with «cold» and «hot» extracts from luminous mushrooms produced positive results (Airth, McElroy, 1959; Airth, 1961). In their works, the authors noted that the results of previous studies might be negative due to low concentration of luciferase in the extracts, possible presence of inhibitors and (or) lability of luciferin produced in «hot» extracts. It is important to note that light emission was recorded by the authors only when NAD $(\mathrm{P}) \mathrm{H}$ was added to the reaction medium; this, in their opinion, suggests reversibility of any oxidation processes, affecting the native components. Later, additional information about luciferinluciferase reaction was derived by Airth and Foerster who used luciferin preparations from Armillaria mellea mushroom and luciferase from the mushroom which they identified as luminous mushroom Collybia velutipes, and proposed a scheme (Fig. 5) to describe luciferinluciferase reaction providing for luminescence of mushrooms (Airth, Foerster, 1962, 1964). 
However, here it is important to note several moments. Luciferin (Ln) and «soluble enzyme» preparations, which were used by the authors, were coarse or only partially purified. Luciferase was the preparation of insoluble particles, probably, containing many different substances. What is more, when the luciferin and luciferase preparations were made from some species of luminous mushrooms the luciferinluciferase reaction was negative. The light production reported by the authors seems to be a result of a sophisticated mechanism involving unknown components in the mixture analyzed, and, probably, the decisive step of light-emitting reaction is not reflected by the above scheme (Fig. 5) (Shimomura, 2006). It is not quite clear, either why to prove the hypothesis of luciferin-luciferase nature of high mushrooms' luminescence the authors (Airth, Foerster, 1962, 1964) to extract the substrate (luciferin) used one mushroom species, and for the enzyme (luciferase) - a different one. In addition, to isolate luciferase the authors seems to have erroneously used Collybia velutipes mushroom, identifying it as luminous; later Wassink (1978) showed that this species is not bioluminescent.

Twenty years later, positive results were also produced in analogous studies by different authors who demonstrated luciferin-luciferase reaction with cold and hot extracts from Armillariella mellea mushroom (Kamzolkina et al., 1983, 1984). As in the previous case, the studies were conducted with coarse (non-purified) preparations of luciferin and luciferase. Nevertheless, results of these studies enabled the authors to suggest that mushroom luciferase can be a multienzyme complex consisting of $\mathrm{NAD}(\mathrm{P}) \mathrm{H}$-cytochrome of P-450-reductase and cytochrome P-450. In their opinion the reductase can be a complexstructured enzyme, a part of which is NAD(P) H-oxyluciferin-oxydoreductase. The authors explained failures to obtain steady luminescence in vitro by dissociation of luciferase into individual components and loss of a certain substrate. These works also note similarity of luciferin-luciferase systems in luminous mushrooms and bacteria.

It should be noted that studies of luciferinluciferase nature of higher mushrooms' luminescence were not developed further by these groups. This is proved by lack of later publications of the authors on this subject. Probably this can be due to their failures to extract mushroom luciferase and luciferin in pure form.

In later studies on five luminous mushroom species (Panellus stipticus, Armillaria mellea, Mycena citricolor, Pleurotus japonicus, and Omphalotus olearius), all attempts to demonstrate existence of some protein (enzyme) to catalyze emission of luciferin in any studied mushroom species have not met with success (Shimomura, 1992, 2006). The author of these works emphasized that even though this does not prove, but can signify lack of luciferase in bioluminescent mushrooms.

Recent works of the Brazilian research group demonstrated again the luciferin-luciferase reaction when working with "hot" and "cold" extracts from different species of luminous higher mushrooms (Oliveira, Stevani, 2009; Oliveira et al., 2012a). These studies were also conducted on non-purified preparations of luciferase and luciferin. In our opinion, the Brazilian researchers demonstrated nothing fundamentally new compared to the above mentioned works (Airth, McElroy, 1959; Airth, Foerster, 1962, 1964; Kamzolkina et al., 1983, 1984). The attempt of these researchers to isolate $\mathrm{NAD}(\mathrm{P}) \mathrm{H}$-reductase from Neonothopanus gardneri mushroom (Oliveira et al., 2012b) is obviously a certain achievement. The enzyme was purified from cold extract by ultracentrifugation, gel filtration, affinity chromatography, and electrophoresis. In his presentation at the $17^{\text {th }}$ International Symposium on Bioluminescence and Chemiluminescence, a 

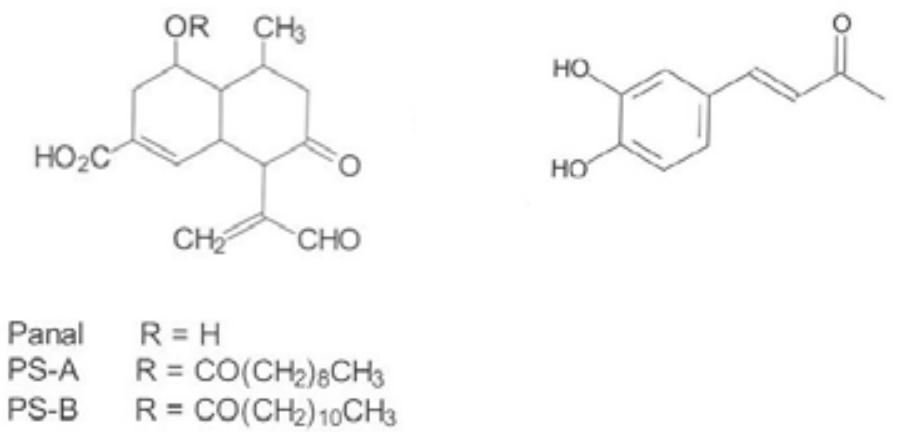

Fig. 6. Structure of luciferin precursors from luminous mushrooms: left - panal, PS-A and PS-B from Panellus stipticus; right - partial structure of the precursor of luciferin from Mycena citricolor (Shimomura, 2006)

researcher of the group, Hans Waldenmaier, told that the co-factor of the NAD(P)H-reductase is FMN, the elimination of which in the enzyme purification stage results in the loss of catalytic activity. The presentation materials do not make it clear whether they were able to produce the enzyme in pure form. Because of the same reasons, it is uncertain whether the authors isolated and characterized the fungal luciferin, as they did not give details (Oliveira et al., 2012c). It cannot be ruled out that the materials presented may be preliminary.

It should be mentioned that attempts to isolate luciferin from luminous mushrooms were made by several groups. Kuwabara and Wassink (1966) extracted luciferin from 15 kilograms of mycelium of Omphalia flavida (grown in PuertoRico on tobacco leaves), and obtained it in a crystalline form. The authors showed that the extracted luciferin exhibits chemiluminescence in the presence of $\mathrm{H}_{2} \mathrm{O}_{2}$, and also that it emits light with a maximum $\lambda_{\max }=524 \mathrm{~nm}$ in the presence of a luciferase preparation produced in Airth process (Airth's luciferase). However, this work gave no information about chemical nature of the luciferin. Endo et al. (1970) extracted from fruiting bodies of Lampteromyces japonicus mushroom several compounds similar to luciferin produced by Kuwabara and Wassink, and a new substance, ergosta-4,6,8(14),22-en-3-one, that exhibited fluorescence with maximum emission $\lambda_{\max }=530 \mathrm{~nm}$, which practically coincides with the maximum of bioluminescence in various mushrooms. Isobe and coauthors isolated from the same mushroom two compounds, riboflavin and lampteroflavin, which fluorescence spectra had emission maximum $\lambda_{\max }=524 \mathrm{~nm}$, practically identical to the bioluminescence of the mushroom (Isobe et al., 1987, 1988). However, O'Kane et al. (1994) excluded riboflavin as the emitter of mushroom bioluminescence on the basis of their spectral studies. In our opinion, the fluorescence spectra cannot be a satisfactory argument for the compound (compounds) extracted from mushroom biomass, regarding the emitter of fungal bioluminescence. It is quite probable that luminous mushrooms may contain various fluorescent compounds, and the fluorescence spectra of some of them may coincide with the emission spectra of luminous mushrooms (Shimomura, 2006). Therefore, to make a more well-founded conclusion it is important to show that a compound extracted from the mushroom biomass actually simulates fungal glow and is involved in the light emission reaction.

Fungal luciferin precursors produced for the first time in pure states were panal, PS-A and PS-B (Fig. 6). They were extracted from luminous 


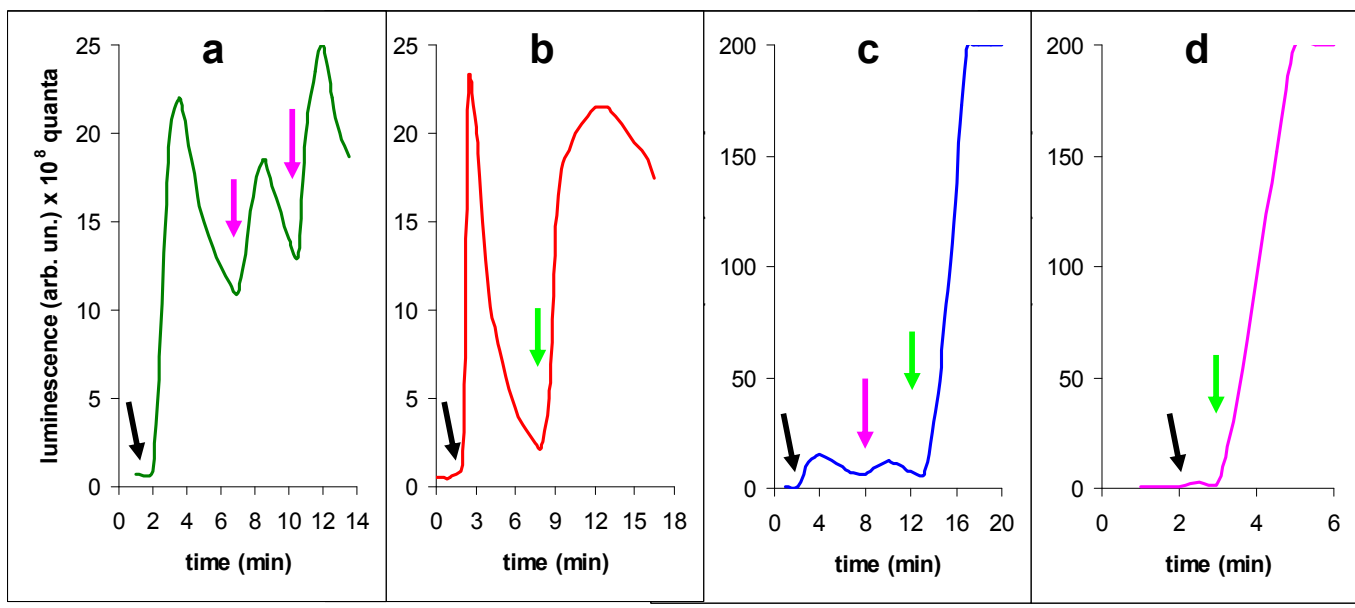

Fig. 7. Luminescence of $N$. nambi mycelium stimulated by different components: a - successive additions of activator-containing extract; $\mathrm{b}$ - single addition of hydrogen peroxide; $\mathrm{c}$ - successive additions of first extract and then hydrogen peroxide; $\mathrm{d}$ - another addition of hydrogen peroxide to the sample (c) after its light emission dropped to steady-state level. Black arrows show moments when globules of mycelium were added into the measurement cell, and additions of components are designated by pink (activator-containing extract) and green (hydrogen peroxide) arrows

mushroom Panellus stipticus; their structures and properties were studied fairly well (Shimomura, 1989; Nakamura et al., 1988; Shimomura, 1991; Shimomura et al., 1993). Further on, some luciferin precursors in pure states were obtained from luminous mushroom Mycena citricolor (Fig. 6), and their properties underwent fairly complete study (Shimomura, 2006).

Recently, extracts from the mycelium of light-emitting mushroom Neonothopanus nambi have been found to contain a thermally stable low molecular weight component that activates the luminescence of the mushroom (Bondar et al., 2011; Bondar et al., 2012a; Bondar et al., $2012 b)$. The activator was discovered in the submembrane fraction of extracts ultrafiltered through $10 \mathrm{kDa}$ membrane; it retained the stimulating effect after boiling at $100^{\circ} \mathrm{C}$ for several minutes and after concentrating for long periods of time at temperatures $45^{\circ} \mathrm{C}$ and $60^{\circ} \mathrm{C}$; it stimulated luminescence of the mycelium, and the luminescence increased by several orders with the addition of hydrogen peroxide (Fig. 7).
Spectral analysis of extracts showed (Fig. 8) two main peaks in the short-wave range (210 and $255 \mathrm{~nm}$ ) and a slight bulge in the $400 \mathrm{~nm}$ range. The authors found that the activator-containing extracts exhibit fluorescence in the visible range (wavelength range $480-630 \mathrm{~nm}$ ) with a maximum at $520-537 \mathrm{~nm}$ (Fig. 8), which coincides with the data of luminescence spectrum of $N$. nambi mycelium in vivo (Bondar et al., 2011). It can be argued that the extracts contain the emitter of luminescence system of $N$. nambi mushroom; thus, the authors proposed to call it nambin. The authors noted that to extract nambin in pure form and to find its structure and physical-chemical properties are the top priority challenge in further research.

An alternative concept of the luminescence mechanism of higher mushrooms, namely, chemiluminescent reaction that does not involve a specialized enzyme is based on the analysis of the results obtained by various authors.

To date, there are experimental facts indicating that higher mushrooms which do 

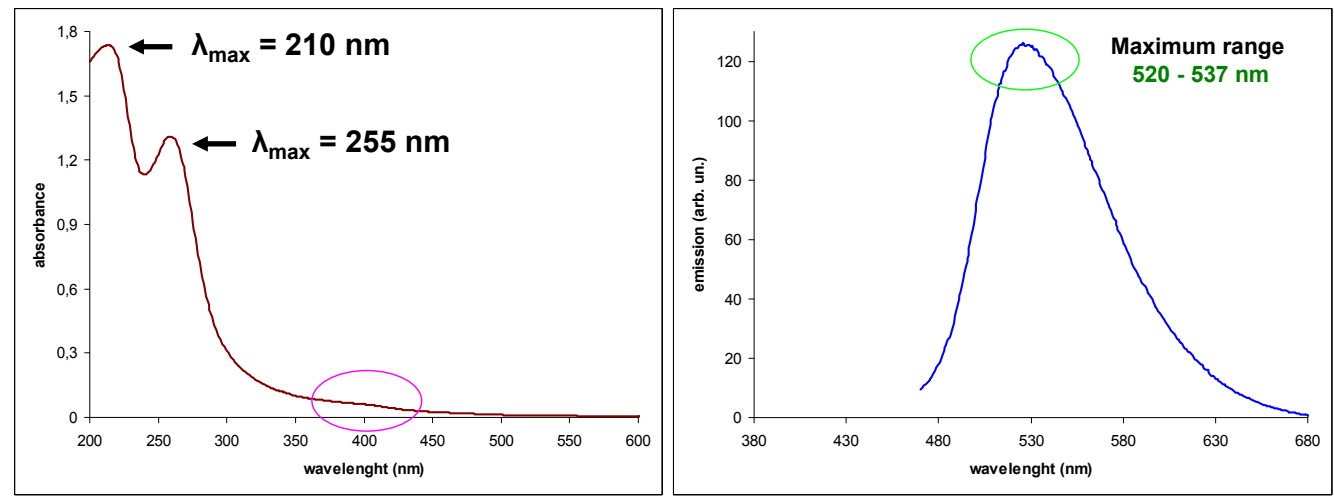

Fig. 8. Spectral characteristics of extracts from Neonothopanus nambi mycelium: left - absorption spectrum, right - fluorescence spectrum (Bondar et al., 2012b)

not show a visible luminescence, however, exhibit weak chemiluminescent emission. For instance, the occurrence of chemiluminescent substances in non-luminous strain of luminous mushroom Panellus stipticus was described by Shimomura (1989). Luminescence of the hyphea in 13 mushroom species, representing phyla Basidiomycota, Ascomycota and Zygomycota, was found by Mihail and Bruhn (2007). Studies on the fruiting bodies of scores of mushroom species from boreal and tropical zones showed that most, if not all, of them have chemiluminescence of various intensity (Fig. 9, 10) (Gitelson et al., 2012a; Gitelson et al., 2012b; Dao et al., 2012). Totality of these data allows assuming fairly confidently that the chemiluminescent emission is inherent to metabolism of higher mushrooms. In turn, this made possible to suggest that fungal chemiluminescence is the metabolic basis from which visible bioluminescence of mushrooms evolved (Gitelson et al., 2012a, 2012b; Dao et al., 2012). According to the hypothesis formulated by McElroy and coauthors (McElroy, Strehler, 1949; McElroy, Seliger, 1961, 1962) and later developed in the works of other authors (Watanabe et al., 1993; Barros, Bechara, 1998; Labas, Gordeeva, 2003; Szpilewska et al., 2003; Katsev et al., 2004), the function of this ancestral emission is to protect living organisms from damage by active forms of oxygen. The function of chemiluminescence in fungi may be analogous. Clearly, this issue requires further study.

It was earlier mentioned that Kuwabara and Wassink (1966) isolated from Omphalia flavida mushroom the luciferin that exhibited chemiluminescence. This work showed that chemiluminescence of luciferin was observed in the presence of $\mathrm{H}_{2} \mathrm{O}_{2}$ with or without additions of $\mathrm{Fe}^{2+}$. Later studies of five species of luminous mushrooms (Panellus stipticus, Armillaria mellea, Mycena citricolor, Pleurotus japonicus, and Omphalotus olearius) established that all of them contained chemiluminescent substances capable of emitting light in the presence of Fenton reagent $\left(\mathrm{H}_{2} \mathrm{O}_{2}\right.$ and $\left.\mathrm{Fe}^{2+}\right)$ (Shimomura, 1992, 2006), forming the basis to assume possible involvement of active forms of oxygen (specifically, superoxide anion $\left(\mathrm{O}_{2}^{-}\right)$) in luminescence of luminous mushrooms. Such active form of oxygen is known to be necessary for several bioluminescent systems to function, e.g., tubeworms Chaetopterus (Shimomura, Johnson, 1966), scaleworms Harmothoe (Nicolas et al., 1982), and mollusks Pholas (Michelson, 1978). The mechanism of $\mathrm{O}_{2}^{-}$action is assumed to involve one-electron oxidation of luciferin 


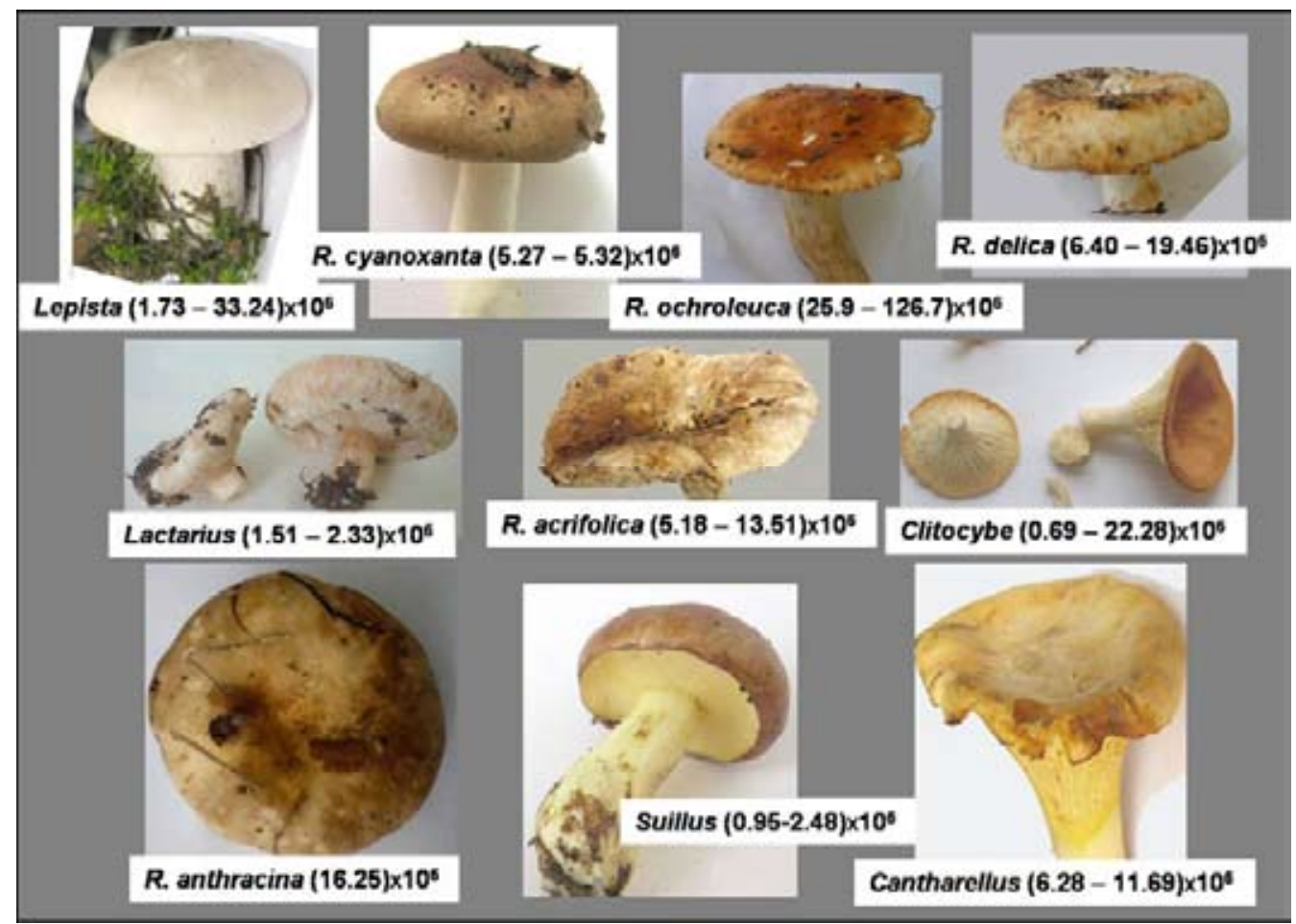

Fig. 9. Diversity of species of higher mushrooms exhibiting chemiluminescence and Numbers designate specific luminous intensity of fruiting bodies, quanta $\cdot \mathrm{s}^{-1} \cdot \mathrm{g}^{-1}$

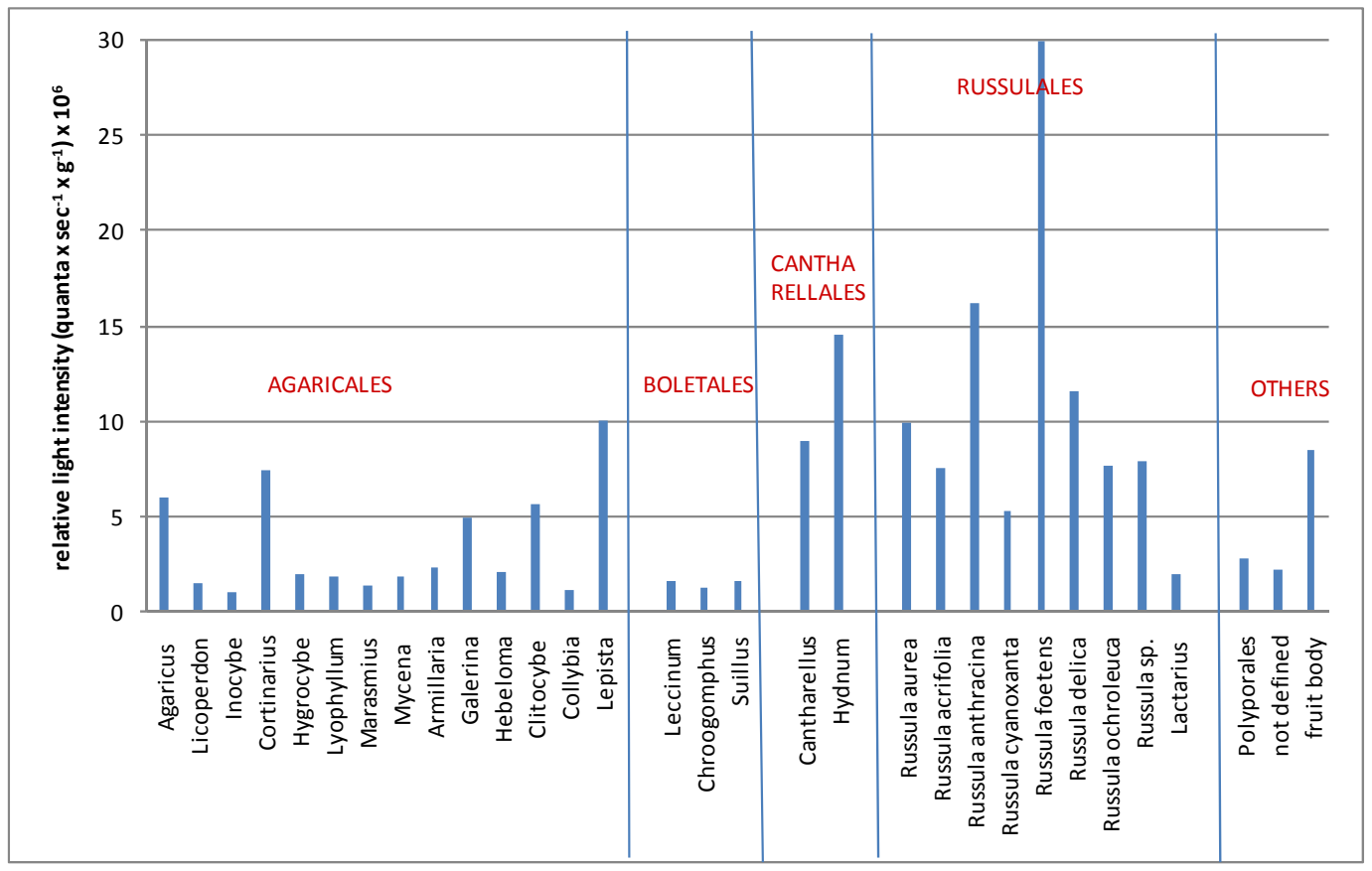

Fig. 10. Chemiluminescence intensity of fragments of the fruiting body of various higher mushroom species 
molecule to form the free radicals of luciferin that are immediately oxidized by molecular oxygen into peroxides (Shimomura, 1993); and subsequent decomposition of luciferin peroxide provides the energy for light emission.

Studies were carried out on the possible involvement of $\mathrm{O}_{2}{ }^{-}$with the same five mushroom species (fruiting bodies and growing mycelium), including the analysis of interrelations between fungal emission and luciferin content, its precursor, superoxide dismutase (SOD), and catalase (Shimomura, 1992). The results allowed the following statement about possible mechanism of fungal luminescence. In luminous mushrooms, SOD producing cells and the cells containing light-emitting substances are distant or arranged in a way that restricts the diffusion and spreading of SOD. For luminescence to occur, activity of SOD in the tissues should be distributed remotely from the luminescence sites, or there should be very low SOD activity in the luminescence sites. In non-luminous mushrooms these two cell types are very close or are arranged in the manner that facilitates the diffusion of SOD; in this case SOD can quickly diffuse into the light emitting cells, eliminate $\mathrm{O}_{2}{ }^{-}$and block luminescent reaction. In the luminous form, a young mushroom exhibits bright luminescence because the light emitting cells are almost not affected by SOD, even though luminescence gradually decreases with time due to slow diffusion of SOD into the light emitting cells. On the basis of this assumption it may be possible to explain some experimental facts found in the investigation of mushroom bioluminescence. For instance, as it was described earlier, the destruction of mushroom is always accompanied by the disappearance of luminescence (Buller, 1924; Harvey, 1952). As to the considerable increase of luminescence intensity of Armillaria mellea mycelium after soaking it in water, which the author observed in his studies, he explains it by washing SOD out of the biomass (Shimomura, 2006).

Considering the evidence described above, it is reasonable to suggest the involvement of active forms of oxygen in the light emitting reaction of higher mushrooms. This may indicate that the mechanism of mushroom luminescence involves oxidase enzymes for the oxidation of organic substrates. Such a view is held by researchers who studied bioluminescence of the luminous mushroom Neonothopanus nambi (Bondar et al., 2011; Bondar et al., 2012a; Bondar et al., 2012b). Experiments with globular mycelium (Fig. 3) grown deep in vials showed that the Fenton reagent $\left(\mathrm{Fe}^{2+}\right.$ and $\left.\mathrm{H}_{2} \mathrm{O}_{2}\right)$ does not stimulate luminescence in the case of $N$. nambi. However, luminescence was stimulated by the additions of hydrogen peroxide only (Fig. 7), which may be an indicative of the involvement of peroxidase or peroxidases in mushroom luminescence mechanism. It was also established that after the addition of an extract containing probable luminescence emitter nambin (see above) to mycelial globules, subsequent addition of hydrogen peroxide increased luminescence substantially and quickly - often exceeding the initial level of luminescence by several orders. Emission intensity of mycelial globules can be so high, that it is visible in darkness by naked eyes, and the high luminescence level can continue for several hours. After the luminescence decreases to the initial steady state level, a new addition of $\mathrm{H}_{2} \mathrm{O}_{2}$ produces a rapid spike of emission with the light signal amplitude comparable to the initial one (Fig. 7). It should be emphasized that luminescence of $N$. nambi can be stimulated repeatedly without new additions of extract. This may be additional evidence that favors the presence in the extract of the luminescence emitter that is not spent in the course of luminescence reaction, thus providing the possibility of repeated stimulation of luminescence. The luminescence of $N$. nambi 


\section{Mechanism of the well-known luminol - peroxide reaction}

$$
\text { luminol }+\mathrm{H}_{2} \mathrm{O}_{2} \underset{\begin{array}{c}
\text { Catalyst: } \\
\text { bivalent ions (Fe, Mn, Cu)/ or heme / or } \\
\text { oxidases (peroxidases) }
\end{array}}{\rightarrow} \alpha \text {-aminoftalic acid }+\mathrm{N}_{2}+\mathbf{h} \sqrt{ }
$$

\section{Mechanism of a hypothetical chemiluminescent reaction in the fungus}

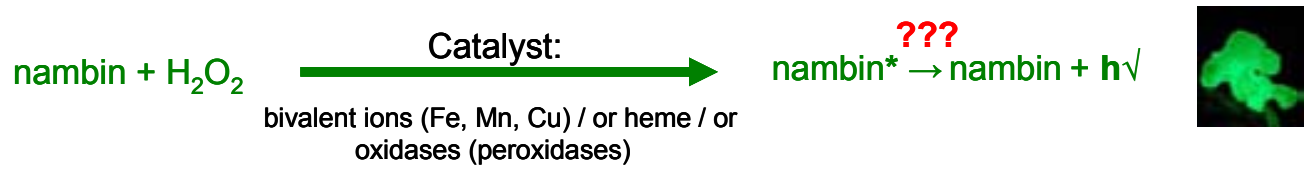

Fig. 11. Chemiluminescent luminol-hydrogen peroxide reaction (top) and assumed chemiluminescent reaction for the luminescence of $N$. nambi mushroom (bottom)

mycelium was shown to be markedly suppressed by the addition of ascorbic acid, an indicative of involving radical mechanisms as the basis of luminescence.

The results produced make possible to suggest that the luminescence mechanism in higher mushrooms may be analogous to the mechanism of well-known luminol $-\mathrm{H}_{2} \mathrm{O}_{2}$ chemiluminescent reaction (Fig. 11) (Bondar et al., 2012b). From the scheme presented it is evident that to activate mushroom emission, a third component reaction catalyst - is required in addition to the emitter and active oxygen forms (e.g., hydrogen peroxide). In the luminol reaction, the role of catalyst is performed by ions of transition metals (e.g., $\mathrm{Mn}, \mathrm{Fe}, \mathrm{Cu}$ ) or enzymes with oxidase function (specifically - peroxidases). It should be noted that $N$. nambi mycelium was found to be stimulated by manganese ions (Bondar et al., 2011). This suggests involvement in mushroom light emission reaction of peroxidase enzymes, e.g., Mn-peroxidase (or Mn-peroxidases) of lignin-destroying enzyme complex. So far transformation of the emitter (nambin) in the course of emission reactions (Fig. 11) remains unknown. At the same time it cannot be ruled out that ergosterine (provitamin $\mathrm{D}_{2}$ ) may be the catalyst (or activator) of fungal luminescence (Bondar et al., 2012b). This version seems valid for two reasons. First, ergosterine is among the most important components of the mushroom cell wall that provide the cell wall with an integrity, fluidity and barrier function, and the activities of enzymes associated with it (Sergeev, Sergeev, 2003). Second, ergosterine is also a well-known activator (intensifier) of chemiluminescence in the tissues of a living organism providing higher quantum yields (Zhuravlev, Zhuravleva, 1975). However, this version requires additional investigation.

As previously reported by other authors studied of bioluminescent mushroom N. nambi, various methods of mechanical destruction of mycelium result in irreversible loss of luminescence activity (Bondar et al., 2011; Bondar et al., 2012b). Thus, the authors suggested that the luminescent system of $N$. nambi may be localized on the cell wall or in the structural elements of the mushroom cell wall. Such an assumption is favored by the results of recent studies of luminous mycelium of Panellus stipticus ((Bull: Fr.) Karst., IBSO 


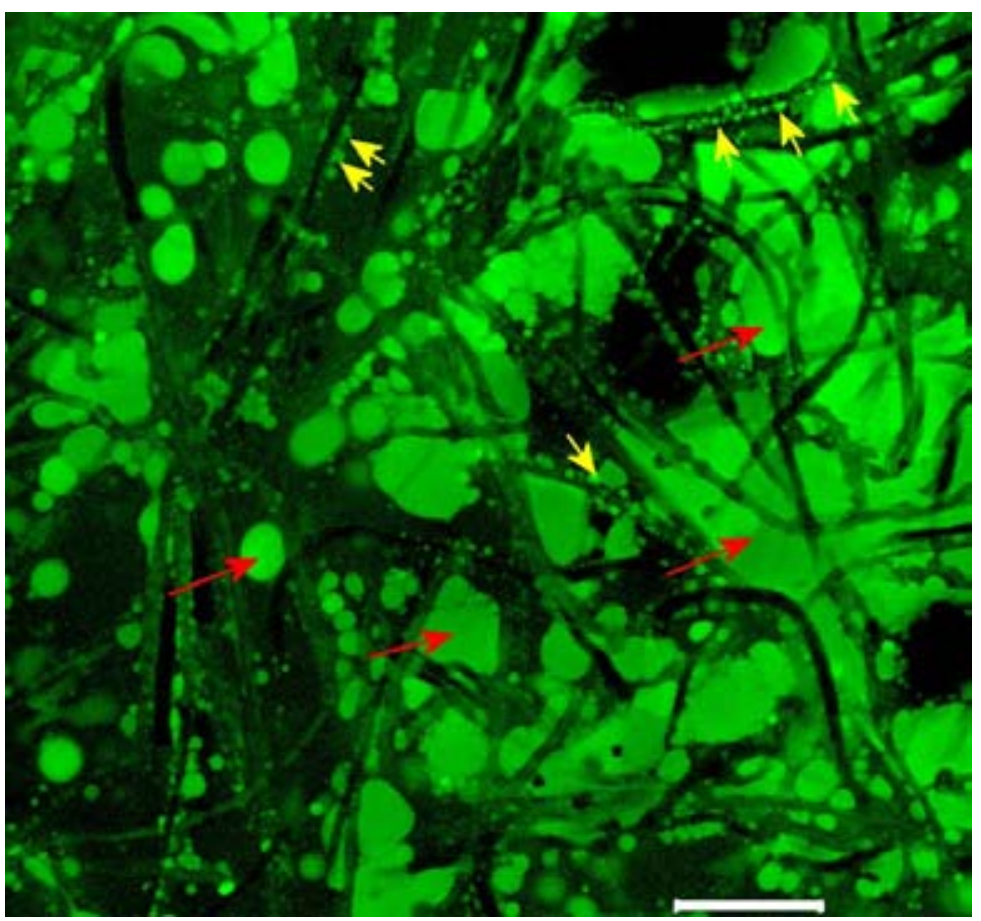

Fig. 12. Luminescent formations, recorded by confocal scanning microscopy in Panellus stipticus grown on solid nutrient medium: local formations on the surface of hyphae (yellow arrows); vast areas in the agar (red arrows). Marker $-20 \mu \mathrm{m}$. (photo by A.P. Puzyr and A.E. Burov)

2301) by confocal microscopy (Puzyr et al., 2012a; Puzyr et al., 2012b). In these studies, the authors were the first to find local luminous structures associated with the outer surface of substrate hyphae and luminous fields in the nutrient agar (Fig. 12). Obviously, these data give new insight into the possible organization of luminescent systems in luminous mushrooms and the mechanisms of their luminescence.

The above data on luminous mushroom $N$. nambi give new insight into the structuralfunctional organization and physical-chemical properties of luminescent system of not only for this species, but also for the light-emitting mushrooms in general. The data in favor of the localization of luminescent system on the cell wall suggest the following scheme of luminescence activation and the mechanism (Fig. 13) (Bondar et al., 2012b). Factors to stimulate fungal luminescence are the processes attended by the formation of active oxygen forms. Their formation can be stimulated by mechanical, physical or chemical impacts on the mushroom cell wall. This may be also associated with metabolic changes in mushroom which disturb enzyme system operation (specifically, of enzymes of the ligninolytic complex, P-450 cytochrome system and respiratory chain) to form active oxygen forms. The chemiluminescent reaction as the basis of mushroom luminescence, in turn, may be supported by those enzyme systems catalyzing oxidation of organic substrates (including emitter) with participation of active oxygen forms. The idea about possible involvement of the peroxidases of ligninolytic complex and P-450 cytochrome system in the chemiluminescent mechanism of the luminescence of $N$. nambi mushroom was already suggested (Bondar et al., 2011; Bondar et al., 2012a). 


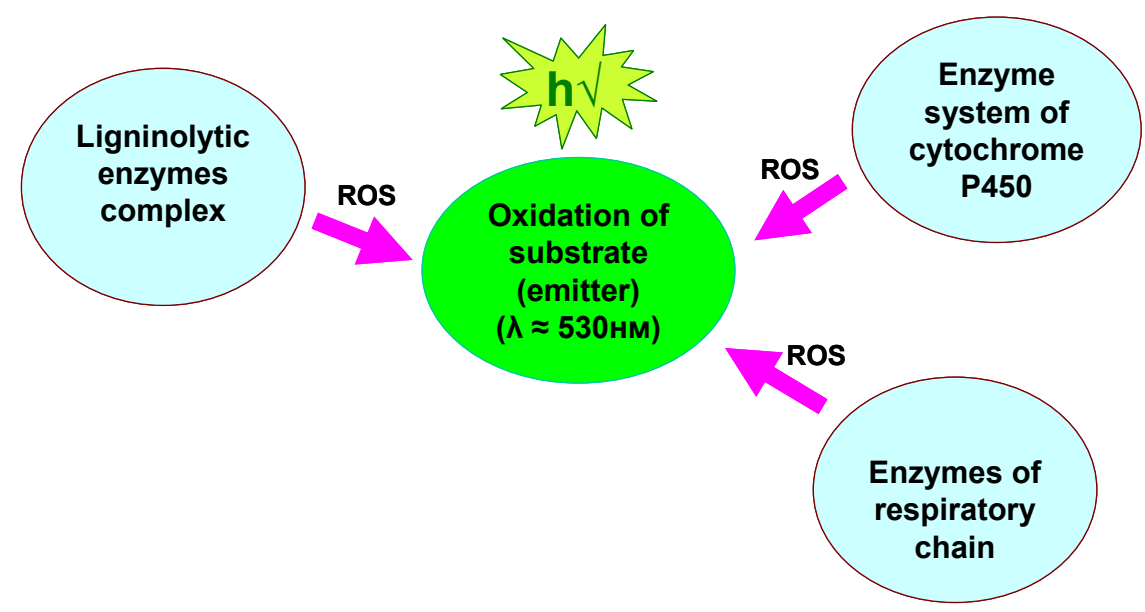

Fig. 13. Hypothetical scheme of possible mechanisms of the chemiluminescent light-emission of higher mushrooms

In our opinion, the proposed scheme (Fig. 13) is in agreement with, and also explains the results of several authors whose works were considered in the present review, and helps develop concepts of the chemiluminescent light-emission of higher mushrooms that do not involve a specialized enzyme.

In summary, this review retrospectively presents experimental facts established by researchers on fungal luminescence in the recent two hundred years. In concluding the review, it would be expedient to make several conclusions. Even though luminescence mechanism of higher mushrooms is not clearly understood, significant results produced in recent years give new insight into the nature of the light emission of higher fungi. This allows expressing a hope that the mechanism of luminescence of higher fungi will be disclosed in not too distant future. Results of several studies considered in the review suggest that it is different from known mechanisms of luminescence of other organisms, such as bacteria, invertebrates, animals and fish. On this basis, we believe that to transcript of the mechanism of mushroom luminescence will be important not only for fundumental biology, but also to extend the boundaries of luminescent analysis.

The work has been supported by the Program of the Government of Russian Federation «Measures to Attract Leading Scientists to Russian Educational Institutions» (grant No 11. G34.31.058).

\section{References}

1. Airth R.L. (1961) Characteristics of cell-free bioluminescence. In: Light and Life, McElroy W.D., Glass B., Eds. Baltimore: Johns Hopkins Press. p. 262-273.

2. Airth R.L. Foerster G.E. (1962) The isolation of catalytic components required for cell-free fungal bioluminescence. Arch. Biochem. Biophys. 97: 567-573.

3. Airth R.L., Foerster G.E. (1964) Enzymes associated with bioluminescence of Panus stipticus luminescens and Panus stipticus nonluminescens. J. Bacteriol. 88: 1372-1379. 
4. Airth R.L., McElroy W.D. (1959) Light emission from extracts of luminous fungi. J. Bacteriol. 77: 249-250.

5. Barros M.P., Bechara E.J. (1998) Bioluminescence as a possible auxiliary oxygen detoxifying mechanism in elaterid larvae. Free Radic. Biol. Med. 24: 767-777.

6. Bermudes D., Gerlach V.L., Nealson K.H. (1990) Effects of culture conditions on mycelial growth and luminescence in Panellus stipticus. Mycologia. 82: 295-305.

7. Bermudes D., Petersen R.H., Nealson K.H. (1992) Low-level bioluminescence detected in Mycena haematopus Basidiocarps. Mycologia. 84: 799-802.

8. Blinks J.R., Prendergast F.G., Allen D.G. (1976) Photoproteins as biological calcium indicators. Pharmacol. Rev. 28: 1-93.

9. Blinks J.R., Wier W.G., Hess P., Prendergast F.G. (1982) Measurement of Ca++ concentrations in living cells. Prog. Biophys. Mol. Biol. 40: 1-114.

10. Bondar V.S., Puzyr A.P., Purtov K.V., Medvedeva S.E., Rodicheva E.K., Gitelson J.I. (2011) The luminescent system of the luminous fungus Neonothopanus nambi. Dokl. Biochem. Biophys. 438: $138-140$.

11. Bondar V.S., Puzyr A.P., Purtov K.V., Medvedeva S.E., Rodicheva E.K., Kalacheva G.S., Gitelson J.I. (2012a) A study of Neonothopanus nambi luminescent system. Luminescence. 27: 101-102.

12. Bondar V.S., Rodicheva E.K., Medvedeva S.E., Tyulkova N.A., Tyaglik A.B., Shpak B.A., Gitelson J.I. (2012b) About mechanism of light emission the fungus Neonothopanus nambi. Dokl. Biochem. Biophys. (in press).

13. Boyle R. (1668) Experiments concerning the relation between light and air in shining wood and fish. Phil. Trans. 2: 581-600.

14. Brock M., Jouvion G., Droin-Bergère S., Dussurget O., Nicola M.A., Ibrahim-Granet O. (2008) Bioluminescent Aspergillus fumigatus, a new tool for drug efficiency testing and in vivo monitoring of invasive aspergillosis. Appl. Environ. Microbiol. 74: 7023-7035.

15. Buller A.H.R. (1924) The bioluminescence of Panus stipticus. In: Researches on Fungi. Vol.III. London: Longmans, Green and Company. p. 357-431.

16. Dao T.V. (2009) Pilot culturing of a luminous mushroom Omphalotus af. illudent (Neonothopanus nambi). Biotechnology. 6: 29-37.

17. Dao T.V., Manukovsky N.S., Gitelson J.I. (2012) Chemiluminescence of cultivated mushrooms of Vietnam. Dokl. Biochem. Biophys. (in press).

18. Desjardin D.E., Oliveira A.G., Stevani C.V. (2008) Fungi bioluminescence revisited. Photochem. Photobiol. Sci. 7: 170-182.

19. Desjardin D.E., Perry B.A., Lodge D.J., Stevani C.V., Nagasawa E. (2010) Luminescent Mycena: new and noteworthy species. Mycologia. 102: 459-477.

20. Dubois R. (1887) Note sur la fonction photog'enique chez la Pholas dactylus. C. R. Soc. Biol. 39: 564-566.

21. Endo M., Kajiwara M., Nakanishi K. (1970) Fluorescent constituents and cultivation of Lampteromyces japonicus. J. Chem. Soc. D: Chem. Commun. 1970: 309-310.

22. Ewart J. (1906) Note on the phosphorescence of Agaricus (Pleurotus) candescens, Müll. Victorian Nat. 23: 174.

$$
-347-
$$


23. Gitelson J.I., Bondar V.S., Medvedeva S.E., Rodicheva E.K., Vydryakova G.A. (2012a) Chemiluminescent emission of tissues of fruit bodies of higher fungi. Dokl. Biochem. Biophys. 443: 105-108.

24. Gitelson J., Bondar V., Rodicheva E., Medvedeva S., Vydryakova G. (2012b) Chemiluminescence of higher fungi. Luminescence. 27: 118.

25. Gitelson J.I., Rodicheva E.K., Medvedeva S.E., et al. (1984) In: Luminous Bacteria, Kondrat'eva E.N., Ed. Novosibirsk: Nauka. 277 p.

26. Harvey E.N. (1922) Studies on bioluminescence. XIV. The specificity of luciferin and luciferase. J. Gen. Physiol. 4: 285-295.

27. Harvey E.N. (1952) Bioluminescence. New York: Academic Press. 649 p.

28. Harvey E.N. (1957) A history of luminescence from the earliest times until 1900. Baltimore, Maryland: J.H. Furst Company. 768 p.

29. Herring P.J. (1994) Luminous fungi. Mycologist. 8: 181-183.

30. Hollis R.P. (1999) Construction and application of a luminescent eukaryotic biosensor. PhD Thesis, University of Aberdeen.

31. Hollis R.P., Killham K., Glover L.A. (2000) Design and application of a biosensor for monitoring toxicity of compounds to eukaryotes. Appl. Environ. Microbiol. 66: 1676-1679.

32. Horswell J., Weitz H.J., Percival H.J., Speir T.W. (2005) Impact of heavy metal amended sewage sludge on forest soils as assessed by bacterial and fungal biosensors. Biol. Fertil. Soils. 42: 569-576.

33. Illarionov B.A., Frank L.A., Illarionova V.A., Bondar V.S., Vysotski E.S., Blinks J.R. (2000) Recombinant obelin: cloning and expression of cDNA, purification and characterization as a calcium indicator. Meth. Enzymol. 305: 223-249.

34. Isobe M., Uyakul D., Goto T. (1987) Lampteromyces bioluminescence. I. Identification of riboflavin as the light emitter in mushroom Lampteromyces japonicus. J. Biolum. Chemilum. 1: 181-188.

35. Isobe M., Uyakul D., Goto T. (1988) Lampteromyces bioluminescence. II. Lampteroflavin, a light emitter in the luminous mushroom Lampteromyces japonicus. Tetrahedron Lett. 44: 1169-1172.

36. Johnson F.H., Haneda Y. (1966) Bioluminescence in Progress. Princeton: Princeton University Press. 664 p.

37. Kamzolkina O.V., Bekker Z.E., Egorov N.S. (1984). Extraction of the luciferin-luciferase system from the fungus Armillariella mellea. Biologicheskie Nauki. 1: 73-77.

38. Kamzolkina O.V., Danilov V.S., Egorov N.S. (1983) Nature of luciferase from the bioluminescent fungus Armillariella mellea. Dokl. Akad. Nauk SSSR. 271: 750-752.

39. Katsev A.M., Wegrzyn G., Szpilewska H. (2004) Effects of hydrogen peroxide on light emission by various strains of marine luminescent bacteria. J. Basic Microbiol. 44: 178-184.

40. Kawamura S. (1915) Studies on the luminous fungi Pleurotus japonicus sp. nov. J. Coll. Sci. Tokyo. 35: 1-29.

41. Kratasyuk V.A., Gitelson J.I. (1987) Use of luminous bacteria in bioluminescent analysis. Uspekhi mikrobiologii. 21: 3-30.

42. Kuwabara S., Wassink E.C. (1966) Purification and properties of the active substance of fungal luminescence. In: Bioluminescence in Progress, Johnson F.H., Haneda Y., Eds. Princeton: Princeton University Press, p. 233-245. 
43. Labas Yu.A., Gordeeva A.V. (2003) Light and color of living organisms. Priroda. 2: 25-31.

44. Lavelle M.M.F., Durosay P., Michelson A.M. (1972) Bioluminescence. Luminescence des champignons lumineux. C. R. Acad. Sci. Paris. 275(Serie D): 1227-1230.

45. Lingle W.L. (1989) Effects of veratryl alcohol on growth and bioluminescence of Panellus stipticus. Mycol. Soc. Am. Newslett. 40: 36.

46. Lingle W.L. (1993) Bioluminescence and ligninolysis during secondary metabolism in the fungus Panellus. J. Biolum. Chemilum. 8: 100.

47. McElroy W.D., Seliger H.H. (1961) Mechanisms of bioluminescent reactions. In: Light and Life, McElroy W.D., Glass B., Eds. Baltimore: Johns Hopkins Press, p. 219-257.

48. McElroy W.D., Seliger H.H. (1962) Origin and evolution of bioluminescence. In: Horizons in Biochemistry, Kasha M., Pullman B., Eds. New York: Academic Press., p. 91-101.

49. McElroy W.D., Strehler B.L. (1949) Factors influencing the response of the bioluminescent reaction to adenosine triphosphate. Arch. Biochem. 22: 420-433.

50. Mendes L.F., Stevani C.V. (2010) Evaluation of metal toxicity by a modified method based on the fungus Gerronema viridilucens bioluminescence in agar medium. Environ. Toxicol. Chem. 29: 320-326.

51. Mendes L.F., Bastos E.L., Desjardin D.E., Stevani C.V. (2008) Influence of culture conditions on mycelial growth and bioluminescence of Gerronema viridilucens. FEMS Microbiol. Lett. 282: 132-139.

52. Michelson A.M. (1978) Purification and properties of Pholas dactylus luciferin and luciferase. Meth. Enzymol. 57: 385-406.

53. Mihail J.D., Bruhn J.N. (2007) Bioluminescence is widespread within the Kingdom of fungi. Opera Mycologica. 1: 28-33.

54. Morin J.G. (1974) Coelenterate bioluminescence. In: Coelenterate Biology: Reviews and Perspectives, Muscatine L., Lanhoff H.M., Eds. New York: Academic Press, p. 397-438.

55. Nakamura H., Kishi Y., Shimomura O. (1988) Panal: a possible precursor of fungal luciferin. Tetrahedron. 44: 1597-1602.

56. Nicolas M.T., Bassot J.M., Shimomura O. (1982) Polynoidin: a membrane photoprotein isolated from the bioluminescent system of scale-worms. Photocbem. Photobiol. 35: 201207.

57. O'Kane D.J., Fuhrer B., Lingle W.L. (1994) Spectral studies of fungal bioluminescence. In: Bioluminescence and Chemiluminescence: Fundamentals and Applied Aspects, Campbell A.K. et al., Eds. Chichester: John Wiley \& Sons, p. 552-555.

58. O'Kane D.J., Lingle W.L., Porter D., Wampler J.E. (1990) Spectral analysis of the bioluminescence of Panellus stipticus. Mycologia. 82: 607-616.

59. Oliveira A.G., Stevani C.V. (2009) The enzymatic nature of fungal bioluminescence. Photochem. Photobiol. Sci. 8: 1416-1421.

60. Oliveira A.G., Carvalho R.P., Stevani C.V. (2012c) On the purification of the fungal luciferin. Luminescence. 27: 150.

61. Oliveira A.G., Desjardin D.E., Perry B.A., Stevani C.V. (2012a) Evidence that a single bioluminescent system is shared by all known bioluminescent fungal lineages. Photochem. Photobiol. Sci. 11: 848-852. 
62. Oliveira A.G., Carvalho R.P., Waldenmaier H.E., Viviani V.R., Stevani C.V. (2012b) On the purification of the $\mathrm{NAD}(\mathrm{P}) \mathrm{H}$-dependent reductase involved in fungal bioluminescence. Luminescence. 27: 151.

63. Puzyr A.P., Burov A.E., Bondar V.S. (2012b) Sources of light emission in a luminous mycelium of the fungus Panellus stipticus. J. Microscopy (in press).

64. Puzyr A.P., Burov A.E., Medvedeva S.E. (2012a) Extracellular bioluminescence of mycelium metabolites of Panellus stipticus (IBSO 2301) luminous mushroom growing on agar medium. Dokl. Biochem. Biophys. (in press).

65. Sergeev A.Yu., Sergeev Yu.V. (2003) Fungal Infections: Manual for Physicians. Moscow: BINOMPress. 440 p.

66. Shimomura O. (1989) Chemiluminescence of panal (a sesquiterpene) isolated from the luminous fungus Panellus stipticus. Photochem. Photobiol. 49: 355-360.

67. Shimomura O. (1991) Superoxide-triggered chemiluminescence of the extract of luminous mushroom Panellus stipticus after treatment with methylamine. J. Exp. Bot. 42: 555-560.

68. Shimomura O. (1992) The role of superoxide dismutase in regulating the light emission of luminescent fungi. Exp. Botany. 43: 1519-1525.

69. Shimomura O. (1993) The role of superoxide anion in bioluminescence. In: Frontiers of Photobiology, Shima A. et al., Eds. Amsterdam: Elsevier Science Publishers, p.249-254.

70. Shimomura O. (2006) Bioluminescence: chemical principles and methods. Singapore: World Scientific Publishing Co. Pte. Ltd. 470 p.

71. Shimomura O., Johnson F.H. (1966) Partial purification and properties of the Chaetopterus luminescence system. In: Bioluminescence in progress, Johnson F.H., Haneda Y., Eds. Princeton: Princeton University Press, p.495-521.

72. Shimomura O., Johnson F.H., Saiga Y. (1962) Extraction, purification and properties of aequorin, a bioluminescent protein from References 437 the luminous hydromedusan, Aequorea. J. Cell. Comp. Physiol. 59: 223-239.

73. Shimomura O., Satoh S., Kishi Y. (1993) Structure and nonenzymatic light emission of two luciferin precursors isolated from the luminous mushroom Panellus stipticus. J. Biolum. Chemilum. 8: 201-205.

74. Szpilewska H., Czyz A., Wegrzyn G. (2003) Experimental evidence for the physiological role of bacterial luciferase in the protection of cells against oxidative stress. Curr. Microbiol. 47: 379382.

75. Ugarova N.N., Brovko L.Yu. (1981) Bioluminescence and bioluminescent analysis: methodological developments. Moscow State University: Chemistry Department.

76. Ugarova N.N., Brovko L.Yu., Kutuzova G.D. (1993) Bioluminescence and bioluminescent analysis: recent development in the field. Biochemistry (Moscow). 58: 976-992.

77. Ugarova N.N., Brovko L.Yu., Trdatyan I.A., Rainina E.I. (1987) Bioluminescent methods of analysis in microbiology. Appl. Biochem. Microbiol. 23: 14-24.

78. Van der Burg A. (1943) Spektrale onderzoekingen over chemo- en bioluminescentie. Thesis, University of Utrecht, Utrecht.

79. Vydryakova G.A., Psurtseva N.V., Belova N.V., Pashenova N.V., Gitelson J.I. (2009) Luminous mushrooms and prospects of their use. Mikol. Fitopatol. 43: 369-376. 
80. Wassink E.C. (1978) Luminescence in fungi. In: Bioluminescence in Action, Herring P.J. Ed. London: Academic Press, p.171-197.

81. Watanabe H., Nagoshi T., Inaba H. (1993) Luminescence of a bacterial luciferase intermediate by reaction with $\mathrm{H}_{2} \mathrm{O}_{2}$ : the evolutionary origin of luciferase and source of endogenous light emission. Biochim. Biophys. Acta. 1141: 297-302.

82. Weitz H.J., Ballard A.L., Campbell C.D., Killham K. (2001) The effect of culture conditions on the mycelial growth and luminescence of naturally bioluminescent fungi. FEMS Microbiol. Lett. 202: 165-170.

83. Weitz H.J. Colin D., Campbell C.D., Killham K. (2002) Development of a novel, bioluminescencebased, fungal bioassay for toxicity testing. Environ. Microbiol. 4: 422-429.

84. Yachevsky A.A. (1933) Fundamentals of Mycology. Moscow-Leningrad: Selkhozgiz. 1036 p.

85. Zhuravlev A.I., Zhuravleva A.I. (1975) Ultra-weak Luminescence of Blood Serum and its Importance in the Complex Diagnosis. Moscow: Medicine. 128 p.

\title{
Свечение высших грибов
}

\author{
В.С. Бондарь ${ }^{\mathrm{a}, \boldsymbol{6}}$, \\ О. Шимомура ${ }^{\mathrm{a}, \mathrm{s}}$, И.И. Гительзон ${ }^{\mathrm{a}, \boldsymbol{0}}$ \\ ${ }^{a}$ Сибирский федеральный университет, \\ Россия 660041, Красноярск, пр. Свободный, 79 \\ ${ }^{\sigma}$ Институт биофизики СО РАН, \\ Россия 660036, Красноярск, Академгородок, 50, стр. 50 \\ ' Лаборатория морской биологии, Вудс Холл, \\ США 02543, Массачусетс
}

В обзоре представлены результаты экспериментальных исследований биолюминесценции грибов, полученные за последние двести лет. Обсуждаются представления о структуре люминесцентной системы и механизме свечения высиих грибов.

Ключевые слова: высшие грибы, биолюминесценция, хемилюминесценция, люцифераза, люииферин, эмиттер. 